\title{
The Invisible Hand of God in Seeds: Jacob Schegk's Theory of Plastic Faculty
}

\author{
Hiro Hirai* \\ Centre for History of Science, Ghent University
}

"To know how the agent of generation acts, and the substance of this agent, is the noblest thing that man can know."

- Moses of Narbonne

\begin{abstract}
In his embryological treatise De plastica seminis facultate (Strasburg, 1580), Jacob Schegk (1511-1587), professor of philosophy and medicine at the University of Tübingen, developed, through a unique interpretation of the Aristotelian embryology, a theory of the "plastic faculty" (facultas plastica), whose origin lay in the Galenic idea of the formative power. The present study analyses the precise nature of Schegk's theory, by setting it in its historical and intellectual context. It will also discuss the hitherto unappreciated Neoplatonic dimension of Schegk's notion of the soul's vehicle.
\end{abstract}

\section{Keywords}

Renaissance embryology, plastic force, soul vehicle, Aristotelianism

\section{Introduction}

In the conclusion of his embryological work On the Formation of Foetus, Galen (129-ca. 216) admits to being ignorant of the cause which forms embryos. Although he recognizes the utmost wisdom and faculty in their formation, he does not believe that the soul in

*) I gratefully acknowledge the help of S. Kusukawa, G. Giglioni, K. Jadoul and M. Iwata in the realisation of the present study. My warmest thanks also go to Caroline Leuris as well as Nobu and Nancy Siraisi. 
semen can construct them. ${ }^{1}$ Inspired by this argument, the humanist physician at Ferrara, Nicolò Leoniceno (1428-1524), wrote a small treatise entitled De virtute formativa (Venice, 1506) on the notion of "formative power" (virtus formativa), which physicians generally thought to be responsible for foetal formation. ${ }^{2}$ Indeed, this notion, whose original term was Galen's "moulding faculty" (dunamis diaplastike), was in vogue during the Middle Ages as an explanation for the formation not only of the foetus but also of natural things in general. In his treatise, Leoniceno criticised the interpretation of Averroes (1126-1198) and Pietro d'Abano (1257-ca. 1315), basing himself on ancient Greek commentators of Aristotle like Simplicius, whose texts were newly made available in Leoniceno's time. It can be said that his discussion, with its philological orientation, opened up a new era of Renaissance embryology. Against Leoniceno's naturalist understanding of the formative power, the French physician Jean Fernel (1497-1558) developed a fully Platonising theory of "divine formative power" for foetal formation in his very influential work, De abditis rerum causis (Paris, 1548). ${ }^{3}$ Following Fernel, Julius Caesar Scaliger (1484-1558), in his extremely popular treatise Exotericae exercitationes (Lyon, 1557) spoke of a "divine force," which formed embryos. ${ }^{4}$

1) Galen, De formatione foxtuum, 6 (Karl G. Kühn, Galeni opera omnia (Leipzig, 18211833), IV, 700 = Diethard Nickel, Galen: Über die Ausformung der Keimlinge (Berlin, 2001), 104).

2) See Vivian Nutton, "The Anatomy of the Soul in Early Renaissance Medicine," in Gordon R. Dunstan, ed., The Human Embryo: Aristotle and the Arabic and European Traditions (Exeter, 1990), 136-157, esp. 138-140 and 152-153; Hiro Hirai, "Semence, vertu formatrice et intellect agent chez Nicolò Leoniceno entre la tradition arabolatine et la renaissance des commentateurs grecs," Early Science and Medicine, 12 (2007), 134-165.

3) See my "Alter Galenus: Jean Fernel et son interprétation platonico-chrétienne de Galien," Early Science and Medicine, 10 (2005), 1-35.

4) Scaliger, Exotericae exercitationes, ex. 6.5 (Lyon, 1557), 14r. Cf. Guido Giglioni, "Girolamo Cardano e Giulio Cesare Scaligero: il dibattito sul ruolo dell'anima vegetativa," in Marialuisa Baldi and Guido Canziani, eds., Girolamo Cardano: le opere, le fonti, la vita (Milan, 1999), 313-339, esp. 319. 
This is the intellectual context of the theory of Jacob Degen alias Schegk (1511-1587). ${ }^{5}$ A native of Schorndorf near Stuttgart in Württemberg, an accomplished humanist and a moderate Lutheran, he taught philosophy and medicine at the Protestant university of Tübingen for several decades. Although he still remains fairly unknown to historians today, it should be noted that his university lectures were very popular and attracted many students, often from reformed lands. Even though Schegk is mainly remembered as a commentator of Aristotle, he was also keenly interested in medical and biological fields. He composed, among other things, an embryological treatise entitled De plastica seminis facultate (Strasburg, 1580). This seems to be the first Renaissance work that applied to the Galenic notion of formative power the term "plastic", which resulted in the expression of "plastic faculty" (facultas plastica). ${ }^{6}$

Although this work is now relatively scarce, Schegk's theory seems to have been known widely among Protestant natural philosophers such as Daniel Sennert (1572-1637) and Johann Amos Comenius (1592-1670) at the turn of the sixteenth and seventeenth centuries. ${ }^{7}$ William Harvey (1578-1678) drew on this theory for his idea of "plastic force" (vis plastica) as the organising agent of embryos in

5) See Dictionary of Scientific Biography, 12 (1975), 150-151; Christoph Sigwart, "Jakob Schegk, Professor der Philosophie und Medizin," in Kleine Schriften (Freiburg im Breisgau, 1889), 256-291; Charles H. Lohr, Latin Aristotle Commentaries: II. Renaissance Authors (Florence, 1988), 410-412; Sachiko Kusukawa, "Lutheran Uses of Aristotle: A Comparison between Jacob Schegk and Philip Melanchthon," in Constance Blackwell and Sachiko Kusukawa, eds., Philosophy in the Sixteenth and Seventeenth Centuries: Conversations with Aristotle (Aldershot, 1999), 169-188. On the natural philosophy at Tübingen in the sixteenth century, see among others Charlotte Methuen, Kepler's Tübingen: Stimulus to a Theological Mathematics (Aldershot, 1998).

6) I have used the following edition: Jacob Schegk, De plastica seminis facultate libri tres (Strasburg: Bernhard Jobin, 1580), indicated hereafter as PSF. On this, see Walter Pagel, New Light on William Harvey (Basel, 1976), 100-103.

7) Daniel Sennert, De chymicorum cum Aristotelicis et Galenicis consensu et dissensu (Wittenberg, 1619), cap. ix. I have used its third edition (Paris, 1633), here, 95-97. On Comenius, see Guido Giglioni, "Spiritus Plasticus between Pneumatology and Embryology (A Note about Comenius' Concept of Spirit)," Studia comeniana et historica 24 (1994), 83-90. 
his epigenesist system. Moreover, it is not only in embryology but also in natural philosophy in general that the notion of plastic power came to play an important role during the seventeenth century. Applying it even to the formation of some minerals and fossils, the Jesuit father Athanasius Kircher (1602-1680) provoked lively debates in the republic of letters. ${ }^{8}$ More importantly, the Cambridge Platonists, Henry More (1614-1687) and Ralph Cudworth (1617-1688), transformed this embryological idea into their own, famous doctrine of "plastic nature." Aimed at explaining the whole organisation of the created world itself rather than the simple generation of natural beings, it held significant metaphysical and theological implications. That is why G.W. Leibniz (1646-1716) was very interested in this doctrine. Thus a single medical theory of Renaissance humanism ultimately contributed to important philosophical debates of the "Scientific Revolution."

In order to be able to evaluate properly the various aspects of later developments, it is necessary to understand first the exact nature of this Renaissance theory in detail. As we shall see, Schegk's formulation already contains the seed of its subsequent transformation. His treatise On the Plastic Faculty of Seed is divided into three books, the first of which deals with the general theory of this faculty, the second with its workings in foetal formation and the third with the intellect. The object of the present study is to analyse Schegk's notion of the plastic faculty, putting it back in its own historical and intellectual context, and to understand precisely the premises of a concept which later developed into the theory of "plastic nature" at the heart of the "Scientific Revolution."

\section{The Plastic Faculty as the Instrument of God}

Schegk opens his discussion by declaring that, among the admirable forces and faculties of natural things, the "formative and plas-

8) Hiro Hirai, "Interprétation chymique de la création et origine corpusculaire de la vie chez Athanasius Kircher," Annals of Science 64 (2007), 217-234. Cf. also William B. Hunter Jr, "The Seventeenth Century Doctrine of Plastic Nature," Harvard Theological Review, 43 (1950), 197-213. 
tic faculty" (facultas formatrix et plastica) is the most remarkable one. For, it fashions from the raw and formless matter of seed an animate body with its parts well formed in terms of quality, figure, number, position, relationship, etc. For Schegk, it is as if all of these parts were made by divine providence and the wisest intellect. By this appeal to transcendent entities, Schegk is alluding to Galen's discussion in the last book of his treatise On the Usefulness of the Parts of the Body, which is in a sense a hymn to the Creator.? "If this plastic force," says Schegk, "is not God himself, who will doubt that it must all the same be called the hand of almighty God?" By continuously generating perishable things with this faculty, God skilfully preserves the perpetuity of the species. This direct comparison of the formative power with the Creator is a further reference to Galen's famous phrase: "I do not know whether this power is the Creator or not." In the scholastic tradition, this phrase was well known through Averroes' quotation of it in his Long Commentary on Aristotle's Metaphysics, VII. ${ }^{10}$ According to Schegk, if the works of Nature and the plastic faculty as the invisible hand of God are contemplated correctly, no one will doubt that God is the wisest being of all. For Schegk, the ultimate goal of the works of Nature is the beauty, for which all movements and generations are destined. God is, he adds, the most excellent being above of all beautiful and good things $\mathrm{He}$ created with his natural instrument, that is, the plastic faculty. Schegk concludes that the wisdom of this divine Arti-

9) Galen, De usu partium, XVII (Kühn, IV, 346-366 = Charles Daremberg, Euvres anatomiques, physiologiques et médicales de Galien (Paris, 1854-1856), II, 201-211 = Margaret T. May, Galen: On the Usefulness of the Parts of the Body (Ithaca, 1968), 724733). Cf. Paul Moraux, "Galien comme philosophe: la philosophie de la nature," in Vivian Nutton, ed., Galen: Problems and Prospects (London, 1981), 87-116; Hirai, "Alter Galenus," 8-11.

10) Cf. Galen, De placitis Hippocratis et Platonis, IX.8 (Kühn, V, 789 = Phillip De Lacy, Galen: On the Doctrines of Hippocrates and Plato (Berlin, 1980), 597); Averroes, Long Commentary on Metaphysics, VII.31 (ed. Giunta, Venice, 1552, VIII, 181 F = Maurice Bouyges, Averroès: Tafsîr mâ ba'd at-tabî̀at (Beirut, 1938-1948), $884=$ Ahmed Elsakhawi, Étude du livre Zây (Dzêta) de la Métaphysique d'Aristote dans sa version arabe et son commentaire par Averroès (Lille, 1994), 117). See now Hirai, "Semence, vertu formatrice," p. 159. 
ficer controls his hands so that the logos is observed not only in his mind but also in his hands.

Schegk then goes on to posit two kinds of efficient cause in the natural world. One is "irrational and material" (alogon kai ulikon). The qualities of the traditional four elements like hot and cold, which "change" something, belong to this category. The other group comprises the form and "reason-principle" (logos), which "generate" something. This includes the "spermatic logos" (logos spermatikos) or "enmattered logos" (logos en hule). ${ }^{11}$ Schegk also qualifies further the spermatic logos as "plastic" (plastikos), that is, formative. This logos is the efficient cause of the generation of animate beings like plants and animals and cannot belong to the matter from which these beings are generated.

To explain the spermatic logos, Schegk first takes up the problem of the term "sperm" (sperma). According to him, Galen applied it on the one hand to seminal liquid in his commentary on Hippocrates' Prognostic and on the other hand to a dunamis or logos in the manner of Aristotle, who did not consider the sperm as material cause but as efficient cause of the foetus. ${ }^{12}$ Schegk points out, however, that Galen used "sperm" in general to designate seminal moisture or matter, saying that the foetus was generated from sperm and blood. That is why he opposed Aristotle in his treatise $O n$ Semen. ${ }^{13}$ But, for Schegk who closely follows Aristotle's definition, sperm does not signify a visible genital or material moisture at all,

11) PSF, I, sig. A1v: "Efficientium proinde causarum in natura duplex est genus, unum

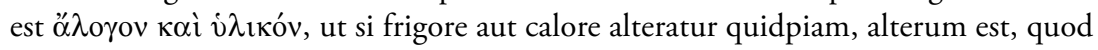

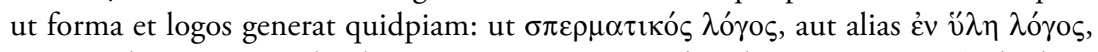
ut si simile generat simile sibi, aut si nutritum assimilat sibi nutrimentum." Elswhere Schegk prefers to use the term $\lambda$ ó $\gamma_{0} \varsigma$ ع̈vv $\lambda$ os, which Aristotle used only once. Cf. Jules Tricot, Aristote: De l'àme (Paris, 1934), 10 n. 2, on Aristotle, On the Soul, I.1, 403a25; Robert B. Todd, Themistius: On Aristotle, On the Soul (London, 1996), 157 n. 46; James O. Urmson and Peter Lautner, Simplicius: On Aristotle's On the Soul 1.1-2.4 (Ithaca, 1995), 164 n. 91.

12) Galen, In Hippocratis Prognosticon, I, 42 (Kühn, XVIII-B, 106). Here Galen speaks of $\theta$ o $\pi \dot{\delta} \delta \eta$.

13) On De semine, see Phillip De Lacy, Galen: On Semen (Berlin, 1998); Michael Boylan, "Galen's Conception Theory," Journal of the History of Biology, 19 (1986), 47-77; Paolo Accattino, "Galeno e la riproduzione animale: analisi del De semine," in Wolf- 
but must be a certain dunamis or logos. Thus he concludes that sperm is a synonym for the spermatic and plastic logos. ${ }^{14}$

Schegk further divides the efficient cause into 1) principal and 2) instrumental. For him, the plastic logos is the instrumental cause whose principal cause is either the parent, who emits seed, or heaven, on which depend all the generations and corruptions of natural things. Schegk goes on to ask whether the plastic logos is animate or inanimate. According to him, if this logos is inanimate, it cannot produce an animate body which is nobler than itself, whereas if it is animate it cannot be the instrument, that is, the dunamis of an animate body, because what is animate is not a dunamis but a body. He says:

Thus it should be concluded that sperm is not an animate or inanimate body, but that it is an instrument for the generation of an animate body. The animate body uses it as a certain instrument for generation [...]. Indeed, since sperm is not a body but a logos and a certain dunamis, it follows then that sperm is not an animate or inanimate body, just as the soul itself is not something animate or inanimate but something non-animate, because it is a logos and a certain entelecheia of an organic body. ${ }^{15}$

Schegk then affirms that the instrument is a "productive potentiality/faculty" (dunamis poietike). The sperm, which is understood as the instrumental cause of the principal agent, is a dunamis and differs from what is in actuality, although no dunamis can be defined without any actuality. For Schegk, something productive cannot

gang Haase, ed., Aufstieg und Niedergang der römischen Welt: II, Principat (Berlin, 1994), XXXVII.2, 1856-1886.

14) See Anthony Preus, "Science and Philosophy in Aristotle's Generation of Animals," Journal of the History of Biology, 3 (1970), 1-52; Gérard Verbeke, "Doctrine du pneuma et entéléchisme chez Aristote," in G.E.R. Lloyd and G.E.L. Owen, eds., Aristotle on Mind and the Senses (Cambridge, 1975), 191-214, esp. 193-194.

15) PSF, I, sig. A2r: "Ex quo concludendum sperma nec animatum, nec inanimatum esse corpus, sed instrumentum generationis animati corporis, quo ad gignendum utatur animatum corpus, tanquam instrumento quodam [...]. Cum enim sperma corpus non sit, sed $\lambda$ ó $\gamma o \varsigma$ et $\delta$ v́ $\alpha \mu \iota \varsigma$ quaedam, sequitur, ut sperma nec animatum, nec inanimatum sit corpus, ut nec anima ipsa est animatum, aut inanimatum quiddam,

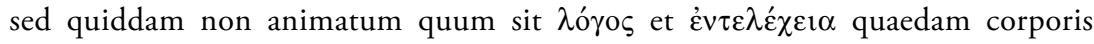
organici." 
belong to matter, but must belong to logos. Then he explains what this spermatic logos really is. First of all, he does not want to mean by the term logos anything relative to the intellect separated from matter, but only the substantial form which resides in natural things. In this connection, he even argues that, at the end of On the Formation of Foetus, Galen admitted to being ignorant of the identity of the soul or the plastic dunamis, asking whether it is corporeal or incorporeal and whether it is a logos or something irrational. ${ }^{16}$ Schegk takes pains to address this doubt and explain what the soul is. For him, it is the substance or entelecheia of a natural organic body. Although it is not corporeal or divisible, it is the principal cause of the affections of this animate body. As an incorporeal principle, it resides in the whole body and in every part of it. The soul is the logos, which "informs" the parts of its matter by the same number of natures as there are these parts. It connects the homoeomerous and non-homoeomerous parts of the body and organises and animates them. Using these organised parts as its organs, the soul obtains powers to perform its actions. ${ }^{17}$

Next Schegk tackles the problem of the term "irrational" (alogon), which occurred in Galen's phrase. For him, if the Greek physician had truly learned from Aristotle the homonymy of the term logos, he would never have wrongly attributed irrationality to natural forms, but would rightly have recognised the forms, which are rational yet devoid of intelligence, as the principles of the actions and passions

16) PSF, I, sig. A3r. Scheck interpolates the part "or the plastic dunamis." Cf. Galen, De formatione foetuum, 6 (Kühn, IV, 700 = Nickel, 104): “[...] I cannot allow that the soul in semen $[\ldots]$ forms foetus, since this kind of soul is not only not intelligent but entirely irrational." Cf. Moraux, "Galien comme philosophe," 114-116; Hirai, "Alter Galenus," 6-7; id., "Semence, vertu formatrice," $\$ 2$. On homoeomerous and nonhomoeomerous parts, see Aristotle, Meteorology, IV.10, 388a10-12, 390b22; Véronique Boudon, Galien: Exhortation à l'étude de la médecine, Art médical (Paris, 2000), 401-402.

17) PSF, I, sig. A3v-A4r. I translate the term informare as "to inform" keeping the sense of "to animate." Cf. Aristotle, On the Soul, II.1, 412a30-35: "This is why the soul is an actuality of the first kind of a natural body having life potentially in it; the body so described is a body which is organised." For a recent revision of the traditional interpretation of this phrase, see A. P. Bos, The Soul and Its Instrumental Body: A Reinterpretation of Aristotle's Philosophy of Living Nature (Leiden, 2003). 
of natural things. According to Schegk, having puzzled over how the logos could be devoid of intelligence, Galen ended up denying the existence of this kind of logos, even though Aristotle had allowed for it. In Schegk's eyes, the Greek physician had ignored the difference between the enmattered logos and the intellectual logos. The former, which informs matter, must be said to be devoid of intelligence and only potentially intellectual:

But Galen denies that the form in matter is a logos, that is, a divine and immutable principle which determines all the natural actions and passions of a thing, so that natural things cannot be found better or more perfectly, and that this form is something divine, beautiful, good and desirable in comparison with the matter, to the extent that deformity comes to matter because of its privation. ${ }^{18}$

Also in the following, Schegk continues to criticise Galen's inconsistency: the Greek physician had on the one hand described the nature of seed as something irrational in his On the Formation of Foetus, but admired on the other hand the perfect logos and the divine providence of the Creator in the works of Nature in his $O n$ the Usefulness of the Parts of the Body. For Schegk, in Nature, there must be non-intellectual logoi. Schegk's Nature is thus "rational", although Nature is not a divine intellect itself. For, it is not necessary for a natural logos to be identical with an intelligence or something endowed with intelligence, even if, like Nature, it does nothing in vain. Schegk adds that the works of Nature differ from the products of art, because the logos of art is an "external" efficient principle, while the natural logos is an "internal" efficient principle. For him, this internal principle for the formation of natural things is created by God and resides in these natural things themselves. The natural logoi produce for the sake of definite ends because these logoi, created by God, imitate the Creator as if they were the hands and instruments of this wisest Artificer. ${ }^{19}$

18) PSF, I, sig. A5v: "At vero Galenus formam in materia negat esse $\lambda$ ó $\gamma o v$, nempe principium divinum et immutabile determinans omnes actiones et passiones rei naturales, ut melius et perfectius habere se nequeant res naturales, et quae forma, respectu

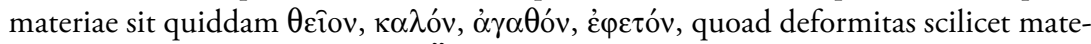
riae propter privationem accidat."

19) PSF, I, sig. A6r-A6v. It is in connection with this instrumentalism that Pagel has 
Schegk concludes his discussion by saying that the plastic faculty, just like the powers of the soul, is not irrational but a natural logos. Although it is devoid of intelligence, it does not produce its effects by chance but for the sake of definite ends, just as Nature does nothing in vain. Then Schegk asks himself: "By gazing at the wonderful works of Nature, who will doubt the wisdom and power of the Creator whose force and potency are diffused everywhere by this instrument?" Thus, although it is not endowed with intelligence, the plastic logos is a rational instrument created by God for the generation of animate bodies.

\section{The Nature of the Plastic Faculty}

Schegk now turns to the problem of the nature of the plastic faculty, namely its identity and the way of its operation. As we have seen, he thinks that the plastic faculty is endowed with reason to form the body of animate beings in the manner of God's hands, although it is itself devoid of intelligence. By dividing the efficient cause into two categories (principal and instrumental), Schegk classifies sperm as a logos or dunamis among the instrumental causes. Since an imperfect being cannot produce anything superior to itself, the sperm alone, which is not animate, cannot produce an animate body. Thus a principal cause is required.

Schegk first explains the double aspect of the instrumental cause. For him, when sperm is in the spermatic vessels of the parent, it remains in potentiality, whereas when it starts to form the foetus, it exists in actuality. By the same token, when a vegetable seed does not perform any action, it remains in potentiality, but when it becomes fertile in earth, it exists in actuality. Schegk adds, however, that heaven intervenes efficiently in all generations, as Aristotle affirms in his Physics, II.2: "Man is begotten by man and by the sun as well." 20

observed the similarity between Schegk and Albertus Magnus. On the latter's theory, Adam Takahashi is preparing a detailed study in his article "Nature, Formative Power and Intellect in the Natural Philosophy of Albertus Magnus," forthcoming.

20) PSF, I, sig. A7r. Cf. Aristotle, Physics, II.2, $194 \mathrm{~b} 14$. 
After having described this double (actual and potential) aspect of the instrumental cause, Schegk quotes another passage of Aristotle's $O n$ the Generation of Animals (hereafter GA), II.1: "For art is both the source and form of the product, but it only exists elsewhere than the product, whereas the movement of Nature exists in the product itself, issuing from another being which has the form in actuality." ${ }^{21}$ As we have seen above, for Schegk, the principle of movement, which resides in the instrument of the artisan, remains outside of the product, whereas the plastic faculty, which forms the body of natural things, is internal. He goes on to affirm that the plastic logos resides in its subject, not as a form that establishes a hylomorphic composite with matter, but as a certain "actuality" (energeia), which executes its work. From here on, the plastic faculty, which has so far been conceived as a kind of productive dunamis, will be explained in terms of energeia.

For Schegk, a principal agent possesses its "species" (eidos) or essence in actuality, whereas an instrument does not possess the species of the agent but only the energeia of the species. The species is not identical with the energeia of the species. To explain this point, Schegk takes recourse to the example of vision. The species of a visible thing resides in its body and stimulates the observer's vision through its energeia, which plays the role of instrument. It is not the species of colour or figure but only the energeia of this species that is dispersed from the body. It is precisely here that Schegk introduces his idea of the "secondary actuality" (actus secundus). For him, the secondary actuality is the energeia of the species, inserted into the instrument and inseparable from the first actuality. Nevertheless, he goes on to say that the seminal secondary actuality is exceptionally separable from the first actuality, just as the inseparable species of the vision are separated by the power of phantasia. ${ }^{22}$ Thus its working is analogous to that of imaginatio. Schegk adds that not the corporeal parts of an animal, which is to come, but only its

21) Aristotle, GA, II.1, 735a2-4.

22) On phantasia and imaginatio, see Marta Fattori and Massimo L. Bianchi, eds., Phantasia-imaginatio (Rome, 1988); Historisches Wörterbuch der Philosophie 7 (1989), cols. 516-535; Nicoletta Tirinnanzi, Umbra naturae: l'immaginazione da Ficino a Bruno (Rome, 2000). 
"productive actuality" (energeia poietike) is contained in the seed. By this special actuality, an animate body can generate another being of the same kind through the seed as its instrument. According to Schegk, the plastic logos is therefore this productive secondary actuality which resides in an instrumental body. He notes, however, that heaven can generate animate beings without the parent of the same kind. This is the phenomenon called "spontaneous generation." It is because, without the parent of the same kind, heaven stimulates in a body composed of elements a weak plastic actuality which can form inferior animate beings. ${ }^{23}$

Then Schegk posits another question: "Is the seminal secondary actuality accidental?" If this actuality is accidental, it cannot generate a substance. But since it fashions animate bodies, it must be substantial. As the first actuality produces by means of the secondary actuality, man generates man through the secondary actuality, which is the spermatic logos. It should be noted here that one of the most extraordinary characters of the plastic faculty in Schegk is its capacity to produce a substance from what is not substantial. He concludes thus that sperm is an instrumental cause as well as the plastic and formative logos, though not enmattered. It is something intermediate between what is animate and what is to be animated. This logos as the secondary actuality, which fashions animate bodies, is the psychic and substantial principle, because it produces a substance, that is, the soul. ${ }^{24}$

23) PSF, I, sig. A7r-A7v. On spontaneous generation in the Renaissance, see my "Earth's Soul and Spontaneous Generation: Fortunio Liceti's Criticism against Ficino's Ideas on the Origin of Life," in Stephen Clucas et al., eds., Laus Platonici Philosophi: Marsilio Ficino and His Influence (Leiden: Brill, forthcoming). Cf. also its French version, "Âme de la terre, génération spontanée et origine de la vie: Fortunio Liceti critique de Marsile Ficin," Bruniana \& Campanelliana, 12 (2006), 451-469.

24) PSF, I, sig. B2r: "Demonstratum hactenus opinior quod videlicet sperma sit instru-

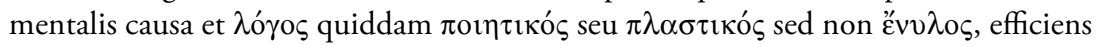
seu generans corpus animatum, et non etiam ipsum animatum existens, medium, inter animatum, et animandum interpositum, sine informatione alicujus materiae ad efficiendum efficax, ut actus, et energeia quaedam secunda." 


\section{Is the Plastic logos Corporeal or Incorporeal?}

Schegk then discusses whether the plastic logos is immaterial (aulos) and whether it is incorporeal, or a certain "incorporeal species" (eidos asomatikon) producing the soul in an organic body. For him, it is evident, however, that this logos is not incorporeal because its efficient cause is an animate body, the parent. Otherwise, this logos would be an intelligence or an intellectual logos, whose cause can never be identified with a body. According to Schegk, intelligence, like the prime mover of the celestial spheres, is an incorporeal being in Aristotle. By contrast, the soul of heaven is corporeal although it is not material, because the body of heaven has no substantial matter, as Averroes teaches. ${ }^{25}$ The celestial soul is corporeal, not because it animates its body (as the soul of perishable things does), but because this soul, inseparably tied to its body, turns by itself with an eternal motion. To those who ask whether the plastic logos is a body or something corporeal, Schegk answers that this logos is not separable from the body, because the plastic dunamis is always tied to a certain body. He adds that intellect and intelligence are separated not only from the material body but also from such a non-material body as that of heaven. ${ }^{26}$ We may thus suppose that, for him, intellect and intelligence are totally separated from corporeity while the plastic logos, like the soul of heaven, is corporeal and inseparable from the body, although it is immaterial. Schegk affirms elsewhere that the plastic logos of each part of the body contains in it immaterial species and can make them enmattered. ${ }^{27}$ Thus it should be understood that the plastic logos, which contains the immaterial species, is immaterial in itself but can be seen as enmattered by the fact that it produces enmattered species in matter.

25) Averroes, De substantia orbis, 1 (Arthur Hymann, "Averroès: A Treatise concerning the Substance of the Celestial Sphere," in Arthur Hyman and James J. Walsh, eds., Philosophy the Middle Ages: The Christian, Islamic, and Jewish Traditions (Indianapolis, 1973), 307-314, esp. 311); Helen Tunik Goldstein, Averroes' Questions in Physics (Dordrecht, 1991), 34 .

26) $P S F, \mathrm{I}$, sig. $\mathrm{B} 2 \mathrm{r}-\mathrm{B} 2 \mathrm{v}$.

27) $P S F$, II, sig. $\mathrm{C} 1 \mathrm{r}$. 
But there is some ambiguity in Schegk's discussion. For he says on the one hand that the plastic logos is corporeal, but on the other hand that this logos is not totally incorporeal. In reality, Schegk regards the plastic logos as not completely incorporeal, unlike an intellectual logos, because it is endowed with "divine body" (corpus divinum) and can generate other animate bodies. It is without doubt because of the relationship with this "divine body" that Schegk thinks that the plastic logos is corporeal. In another passage, where he underlines the difference between the incorporeal logos and the corporeal logos, he distinguishes the intellectual logos from the natural logos which produces form in a natural body. Thus this natural logos must be understood as corporeal. Schegk also asks why the divine intellect cannot give natural logoi to the seeds of living beings just as intellectual logoi are given to man. It is thus reasonable to assume that the plastic logoi are these natural logoi conferred to the seeds.

\section{The Divine Vehicle of the Plastic Faculty}

After this radical re-interpretation of Aristotelian embryology, the discussion takes an unexpected turn, developing into a Neoplatonic dimension. As we have seen, Schegk speaks of a certain "divine body" to which the plastic logos is inseparably tied. Affirming that Aristotle compares the plastic logos with an art that produces nothing without a corporeal instrument, he proposes to seek what this instrumental body really is, by which the plastic logos performs its power. This is how his answer begins:

The Stoics say that a certain ethereal and divine body is the vehicle of the soul itself. Such is also the body of the plastic faculty. The author of the first book $O n$ Regimen in [the corpus of] Hippocrates (Galen denies, however, that this is of Hippocrates) calls it "the creative fire" which advances on its path towards generation, as Zeno, according to Cicero, defines it. ${ }^{28}$

28) PSF, I, sig. B2v: "Stoici dicunt, quoddam $\alpha i \theta \varepsilon \rho \hat{\omega} \delta \varepsilon \varsigma$ esse $\sigma \hat{\omega} \mu \alpha$ divinum, oै $\chi \eta \mu \alpha$ quoddam ipsius existens animae, quale sit etiam corpus plasticae facultatis, quem autor libri primi De diaeta apud Hippocratem (nam Hippocratis, negat esse Galenus) 
Schegk thereupon introduces the Stoic idea of causa continens, which he had already discussed in the introduction to his translation of Alexander of Aphrodisias' (fl. ca. 200 AC) work De mixtione. ${ }^{29}$ On the details of his discussion, where he identifies this cause with God himself who penetrates all, he refers the reader back to this introduction. As for the Hippocratic treatise On Regimen, also called De victus ratione, its author posits a fire which "structures the human body by imitating the universe." ${ }^{30}$ This idea can be interpreted as being very close to the Stoic notion of the divine creative fire. ${ }^{31}$ That is why Schegk places the Stoics at the head of this passage. It should, however, be noted that it is not the author of this Hippocratic treatise who speaks of "a creative fire which advances on its path towards generation," since this is a phrase of Cicero who attributes it to Zeno. The Tübingen professor is in his turn merely copying it here. ${ }^{32}$

Schegk goes on without delay to say that Aristotle calls the ethereal body "what corresponds by analogy to the fifth element." This is of course that famous enigmatic phrase in GA, II.3, which establishes a close connexion between animal generation and the celestial element, the aether. ${ }^{33}$ As we have shown in previous studies,

ignem artificiosum appellat ad gignendum progredientem via, ut ipsum definit Zeno apud Ciceronem."

29) On De mixtione, see Robert B. Todd, Alexander of Aphrodisias on Stoic Physics: A Study of the De mixtione (Leiden, 1976). On his Latin translation (Tübingen, 1540), see F. Edward Cranz, "Alexander Aphrodisiensis," Catalogus translationum et commentariorum, 1 (1960), 77-135, esp. 113.

30) Hippocrates, On Regimen, I.10 (Littré, 484 = Robert Joly and Simon Byl, Hippocrate: Du régime (Berlin, 2003), 134). Cf. Robert Joly, Recherches sur le traité pseudohippocratique Du régime (Paris, 1960), 35-36. On the importance of this treatise in the Renaissance, see my "Prisca Theologia and Neoplatonic Reading of Hippocrates in Fernel, Cardano and Gemma," in Hiro Hirai, ed., Cornelius Gemma (1535-1578): Medicine, Cosmology, and Natural Philosophy in Renaissance Louvain (Rome, forthcoming).

31) See Friedrich Solmsen, "Cleanthes or Posidonius? The Basis of Stoic Physics," Mededelingen der Koninklijke Nederlandse Akademie van Wetenschappen, 24 (1961), 263289; David Hahm, The Origins of Stoic Cosmology (Columbus, 1977); Martin Vanden Bruwaene, Cicéron: De natura deorum (Brussels, 1978), II, 48 n. 73.

32) Cicero, De natura deorum, II.22, 57 (Vanden Bruwaene, 81).

33) Aristotle, GA, II.3, 736b33-737a7. Cf. Friedrich Solmsen, "The Vital Heat, the 
while Leoniceno vigorously refused to appeal to this passage to explain the true nature of the formative power, Fernel responded to it very favourably. In fact, for Fernel, this passage constituted the very foundation of his fully Platonising interpretation of Galen and Aristotle. ${ }^{34}$ As for Schegk, he affirms that this body is not identical at all to the fifth element in these terms:

This body differs from the celestial element because it evidently has no nature separable from its matter or from seminal liquid. Because of this, Aristotle says that it is not celestial but similar by analogy to the celestial [element], or "analogous to the higher element." This body is penetrating through the entire matter, forming and figuring it, and distinguishes it by the natures of its parts [...]. Indeed, this body is totally spiritual and the most kindred to the substance of the plastic logos. It is established that this [logos] is a certain energeia of the first actuality and, so to speak, the secondary yet substantial actuality of another animate and physical body although it is evidently itself not a physical body. For, otherwise, a physical body cannot enter and penetrate its matter, because there is no [mutual] penetration of physical bodies. ${ }^{35}$

Although Leoniceno had previously advanced this kind of "similarity (and non-identity)" of the "divine body" with the aether, we cannot determine whether Schegk had any direct or indirect knowledge of the embryological treatise of the Ferrarese humanist. At any event, concerning this ethereal body, Leoniceno relied upon a phrase by Themistius (ca. 317-ca. 388), which connected the Aristotelian

Inborn Pneuma and the Aether," Journal of Hellenic Studies, 77 (1957), 119-123; David M. Balme, Aristotle's De partibus animalium I and De generatione animalium I (Oxford, 1972), 161-164; Gad Freudenthal, Aristotle's Theory of Material Substance: Heat and Pneuma, Form and Soul (Oxford, 1995), 107-114.

34) See Hirai, "Alter Galenus," 24-28; id., "Semence, vertu formatrice," $\$ 3$.

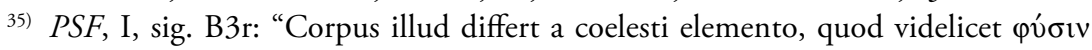
nullam habeat, quae sit separabile a materia sua seu genitali humore. Et ob id Aristo-

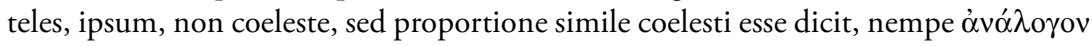

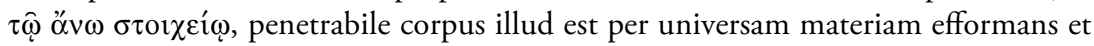
effingens ipsam, naturis partium distinguendo [...]. Nam omnino spirituale est cor-

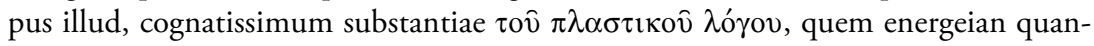
dam primi actus esse constat, et quasi actum secundum, sed substantialem, animati, et physici corporis alterius, ipsum scilicet non physicum corpus existens. Alioqui enim corpus physicum, materiam suam subire et penetrare non potest. Penetratio enim nulla sit physicorum corporum." 
idea of the fifth element to the Neoplatonic idea of the "vehicle" (ochema) of the soul. ${ }^{36} \mathrm{He}$ also used an argument of cardinal Bessarion (1403/8-1472), who revived this theory in his own interpretation of the famous phrase of Aristotle's GA, II.3. ${ }^{37}$

But whereas Leoniceno had not drawn on Galen's own words in On the Doctrines of Hippocrates and Plato, VII.7, Schegk's position is in reality derived directly from Galen's views expressed there:

And if we must speak of the substance of the soul, we must say one of two things: we must say either that it is this, as it were, bright and ethereal (aitherodes) body, a view to which the Stoics and Aristotle are carried in spite of themselves, as the logical consequence (of their teachings), or that it is (itself) an incorporeal substance and this body is its first vehicle (ochema), by means of which it establishes partnership with other bodies. ${ }^{38}$

That is why Schegk finds no problem to place the Stoics and Aristotle in the same position. Citing another passage from Aristotle's GA, II.3- "The faculty of all souls is associated with a body which is different from the so-called elements and more divine than they are; and as the souls differ from one another in the scale of value, so too this sort of body differs" ${ }^{39}$ - Schegk adds that, as souls differ by species from each other, their vehicles also differ by the degree of nobility and ignobility. It is true that the Stagirite speaks of a

36) Themistius, Paraphrase on Aristotle's On the Soul, I.3 (Heinze, 19). On the soul's vehicle, see Eric R. Dodds, Proclus: The Elements of Theology (Oxford, 1933/1963), 315-321; Daniel P. Walker, "The Astral Body in Renaissance Medicine," Journal of the Warburg and Courtauld Institutes, 21 (1958), 119-133; John F. Finamore, Iamblichus and the Theory of the Vehicles of the Soul (Chico, 1985); Henry J. Blumenthal, "Soul Vehicle in Simplicius," in Stephen Gersh et al., eds., Platonism in Late Antiquity (Indiana, 1992), 173-188; Maria di Pasquale Barbanti, Ochema-Pneuma e phantasia nel neoplatonismo: aspetti psicologici e prospettive religiose (Catania, 1998).

37) See Hirai, "Semence, vertu formatrice," $\$ 3$. Cf. Bessarion, In calumniatorem Platonis (Rome, 1469), III.22, 3 (Ludwig Mohler, Kardinal Bessarion als Theologe, Humanist und Staatsmann (Paderborn, 1923-1942), II, 369).

38) Galen, De placitis Hippocratis et Platonis, VII.7 (Kühn, V, 643 = De Lacy, 474). On this treatise in the Renaissance, see Vivian Nutton, "De platicis Hippocratis et Platonis in the Renaissance," in Paola Manuli and Mario Vegetti, eds., Le opere psicologiche di Galeno (Naples, 1988), 281-309.

39) Aristotle, GA, II.3, 736b29-33. 
body which is more divine than the four elements. But, contrary to what Schegk wants his readers to believe, he does not mention the "spiritual vehicle of the soul." This is thus a typical example of the modus operandi of his interpretation.

Next Schegk compares the power of the vehicle of the plastic faculty with the splendour of lights and with the magnetic force of loadstones, both of which are, in his eyes, highly penetrating. Denying the famous Stoic theory of "total blending," that is, the mutual penetration of physical bodies, he advances that the plastic logos, or its divine vehicle, is not physical at all but spiritual. ${ }^{40}$ It is, however, noteworthy that Schegk minimises the influence of the Florentine Neoplatonist Marsilio Ficino (1433-1499), showing no interest in developing the notion of spiritus here, which was so much in vogue in this sixteenth century. ${ }^{41} \mathrm{He}$ simply says that such a divine body is spiritual and impassive as a logos is. For him, this spiritual vehicle can generate, move and establish animate bodies, although it is itself neither animate nor merely natural, but is situated as it were half-way between these two properties.

According to Schegk, Aristotle believes that both the form of the soul and the plastic logos are tied by this spiritual vehicle to an organic body composed of elements. For him, the soul preserves the organic body by means of nutrition, which forms the animate body from inanimate nutriment. This means that the soul produces flesh from what is not flesh and bone from what is not bone. Because of this function, the soul resembles to some degree the plastic faculty, as it participates in the ethereal vehicle. It is through this divine vehicle that the soul also performs other functions like sense-perception and motion. By contrast, the mixtures of elements are brought about directly and without the intervention of this spiri-

40) On the theory of the total blending, see Todd, Alexander on Stoic Physics, 29-73.

41) On Ficinian spiritus, see Daniel P. Walker, Spiritual and Demonic Magic from Ficino to Campanella (London, 1958); Sylvain Matton, "Marsile Ficin et l'alchimie, sa position, son influence," in Jean-Claude Margolin and Sylvain Matton, eds., Alchimie et philosophie (Paris, 1993), 123-192; Hiro Hirai, "Concepts of Seeds and Nature in the Work of Marsilio Ficino," in Michael J.B. Allen et al., eds., Marsilio Ficino: His Theology, His Philosophy, His Legacy (Leiden, 2002), 257-284, esp. 273-276; id., "Alter Galenus," 22-28. 
tual vehicle, with the help of the substantial forms that are incapable of producing any animate body. ${ }^{42}$

Schegk goes in fact even further, arguing that Aristotle calls this divine body an "ensouled heat" (thermos empsychos), which is not fire nor any such force but possesses a "vivifying faculty" (dunamis zotike) like the heat of the sun and that of the residue of animal bodies. ${ }^{43}$ By contrast, what is vivified is composed of elements and cannot vivify any other body at all. With this development, Schegk naturally associates the phrase from GA, III.11, where Aristotle explains spontaneous generation from putrefied matter as follows: "There is water in earth, and pneuma in water, and in all pneuma is soul-heat, so that in a sense all things are full of soul." ${ }^{44}$ According to Schegk, Aristotle wants to express by this "soul-heat" (thermotes psychike) the plastic principle which is generated in putrefied matter and brings about spontaneous generation.

Schegk adds that thanks to its perfect form and analogously to celestial bodies, this divine vehicle plays the role of an instrument by which the plastic logos can alter and moderate the matter of a foetus. As the generative logoi of celestial bodies produce the substance of natural things by moderating and mixing their matter, this divine body, being the instrument of the plastic logos, moderates and mixes the matter of the animate body that is to come about. Thus, for example, the plastic logos, which fashions the heart, moderates the matter for the heart through its celestial vehicle. The plastic logos needs this divine vehicle because, without this intermediary

\footnotetext{
42) $P S F, \mathrm{I}$, sig. B3r-B3v.

43) The term $\theta \varepsilon \rho \mu o ́ \varsigma ~ \varepsilon ̋ \mu \psi v \chi o \varsigma$ is not Aristotle’s. Cf. Aristotle, GA, III.1, 751b6; III.4, 755a20. For a cosmic heat, see Hippocrates, On Flesh, 2 (Littré, VIII, 584); Walter Spoerri, "L'anthropogonie du Peri sarkon (et Diodore, I 7, 3 s.)," in François Lasserre and Philippe Mudry, eds., Formes de pensée dans la Collection hippocratique (Geneva, 1983), 57-70; Freudenthal, Aristotle's Theory, 95-97.

44) Aristotle, GA, III.11, 762a18-21. Cf. Aristotle, On the Soul, I.5, 411a7-11; On the

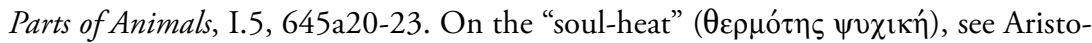
tle, GA, II.1, 732a18; II.4, 739a11; III.1, 752a2. See also Jochen Althoff, "Das Konzept der generativen Wärme bei Aristoteles," Hermes, 120 (1992), 183-193; Gad Freudenthal, "The Medieval Astrologization of Aristotle's Biology: Averroes on the Role of the Celestial Bodies in the Generation of Animate Beings," Arabic Sciences and Philosophy, 12 (2002), 111-137.
} 
body, the plastic energeia cannot remain simply incorporeal nor perform its power. For Schegk, that is why this vehicle, also called "soul-heat" or "divine element," is by necessity in the service of the plastic logos as the instrument of its operations. ${ }^{45}$

\section{The Separability of the Divine Vehicle}

Can the divine vehicle be separated from the matter of seed? As we have seen, it is with the help of this vehicle that the plastic logos generates organic bodies and the soul subsequently informs them. Schegk first appeals to Aristotle's Metaphysics which attests, in his interpretation, that in the realm of perishable, natural forms, no soul except the human one is separable from body. He suggests that Aristotle takes non-human souls as non-separable for the reason that he cannot admit any energeia without its body. He then turns to a passage from GA, II.3, where the Stagirite calls the separated soul "intellect," saying that it comes "from outside." ${ }^{46}$ Schegk feels that it is natural to connect this to yet another passage in $G A$, II.3, which also speaks of the separated intellect: ${ }^{47}$

In the second book On the Generation of Animals, [Aristotle] calls this soul "intellect." He writes that it comes "from outside," that is, from without and that it is not procreated from the potentiality of matter. He writes in the same book that this intellect is received in the matter of seminal liquid and that its vehicle is separable from the matter and from the body of sperm, although the vehicle of the other [souls] are not separated and that the soul of these [beings] does not exist before [this vehicle], because it is generated by the spermatic logos which precedes the entelecheia of the soul in generation. ${ }^{48}$

45) PSF, II, sig. C2r-C2v.

46) Aristotle, GA, II.3, 736b27-29: "It remains, then, that the intellect alone enters in, additionally from outside and that it alone is divine; for the bodily actuality is nothing to do with its actuality." Cf. Paul Moraux, "À propos du vov̂ $\varsigma \theta 0$ $\rho \alpha \theta \varepsilon v$ chez Aristote," in Augustin Mansion, ed., Autour d'Aristote (Louvain, 1955), 255-295; Preus, "Science and Philosophy," 32-34.

47) Aristotle, GA, II.3, 737a7-12: "But the body of the semen, in which there also comes the portion of the principle of the soul - partly separable from body in all those in which something divine is included (and such is what we call the intellect) and partly inseparable." Cf. Verbeke, "Doctrine du pneuma," 210 n. 12.

48) PSF, I, sig. B4v: "Hanc animam, libro secundo De generatione animalium vôิs 
Schegk clearly thinks that, for Aristotle, only the vehicle of the human soul is separable, whereas that of the other souls is inseparable, because the souls of inferior living beings are generated by the plastic logos which exists before the generation of these souls. Concerning the separability of the vehicle of the human soul, Schegk notes that Plato expresses the same idea in his Phaedrus, saying that the eternal human souls enter from outside into the seminal liquid because of the intellect and that they are neither generated nor corrupted at the same time with their body. However, Schegk does not want to touch the issue of metempsychosis, that is, the transmigration of the soul, which he considers a mere fable. ${ }^{49}$

Emphasising his Christian position, Schegk maintains that God alone is the Creator of human souls. And he sums up the opinion of the ancient philosophers as follows: Only the vehicle of the human soul is separable from seminal liquid, thanks to the intellect. The plastic power, given to the spermatic logos, achieves generation with the help of this spiritual vehicle as its instrument. The organic body is formed by this vehicle, which is not the intellect but the divine body, and the soul informs the developed parts of the organic body. Thanks to this vehicle, the human soul enters the body at birth and leaves it at death. That is why, says Schegk, the human soul is called "divine breath" (spiraculum divinum) in Genesis and "man-god" (anthropodaimona) by Euripides. He concludes that, for the ancient philosophers, the human soul alone is sepa-

appellat, quem $\theta \dot{v} \rho \alpha \varepsilon v v$, id est, extrinsecus advenire, et non de potentia materiae pro-

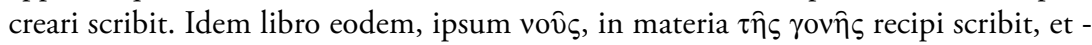
o’ $\chi \eta \mu \alpha$ ipsius a materia, et corpore spermatis esse separabile, cum aliarum ő $\chi \eta \mu \alpha$, non sit $\chi \omega \rho \iota \sigma \tau o ́ v$ et prius horum anima non sit ; quia generetur $\lambda o ́ \gamma \omega \sigma \pi \varepsilon \rho \mu \alpha \tau \iota \kappa \hat{\varphi}$, qui $\gamma \varepsilon v \varepsilon ́ \sigma \varepsilon 1$ praecedat $\dot{\varepsilon} v \tau \varepsilon \lambda \varepsilon^{\prime} \chi \varepsilon 1 \alpha \nu$ animae."

49) Plato does not say as such but this is again Schegk's reinterpretation. Cf. Plato, Phaedrus, 246C. On "metempsychosis" in the Renaissance, see Hirai, "Alter Galenus," 15; François Secret, "Alchimie, palingénésie et métempsychose chez Guillaume Postel," Chrysopæia, 3 (1989), 3-60, esp. 54-55; Jean-Pierre Brach, Guillaume Postel: Des admirables secrets des nombres platoniciens (Paris, 2001), 179-209; Helmut Zander, Geschichte der Seelenwanderung in Europa: Alternative religiöse Traditionen von der Antike bis heute (Darmstadt, 1999), 233-247. 
rable from the body whereas the other souls are inseparable. ${ }^{50}$ What is important for us to remark here is the fact that it is by the plastic logos with the help of its divine vehicle that all the non-human souls are procreated.

\section{Is the Plastic logos a Part of the Soul?}

Schegk then turns to a discussion of whether the plastic logos becomes a part of the soul, which is to be generated, and whether, by a total dissolution, none of its parts remains in the established organic body. He first reminds us that Aristotle proves the dissolution of the plastic logos by the example of a coagulant which perishes and disappears after the coagulation of milk. ${ }^{51}$ For him, when the soul enters the organic body in order to animate it, the plastic logos, disappearing by itself, is replaced by the soul. He gives as proof another passage of Aristotle's GA, II.1: "Now the seed, and the movement and principle which it contains, are such that, as the movement ceases, each part gets formed and acquires the soul." ${ }^{52}$ Schegk continues:

For, the spermatic logos cannot remain in the same subject where the soul resides. Indeed, the plastic logos is in matter from which, thanks to its power, the organic body is generated whereas the soul remains, as entelecheia, in the organic body already established and, once the movement of generation ceases, the plastic logos itself ceases to exist. ${ }^{53}$

50) PSF, I, sig. B4v-B5r. See Genesis, II.7, on the spiraculum vitae of God and Euripides, Rhesos, 971, on the anthropodaimon ( $\alpha v \theta \rho \omega \pi \mathrm{o} \alpha \alpha i \mu \omega \mathrm{v})$.

51) Cf. Aristotle, GA, II.3, 737a13-16: "Therefore we ought not to expect it always to come out again from the female or to form any part of the embryo that has taken shape from it; the case resembles that of the fig-juice which curdles milk, for this too changes without becoming any part of the curdled bulk."

52) Aristotle, GA, II.1, 734b21-24.

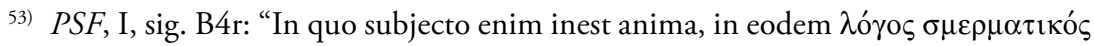

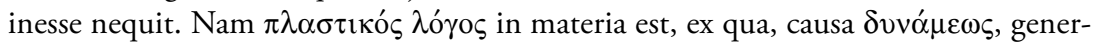
atur organicum corpus, sed anima est, ut $\varepsilon^{\prime} v \tau \varepsilon \lambda \varepsilon^{\prime} \chi \varepsilon 1 \alpha$, in perfecto jam organico cor-

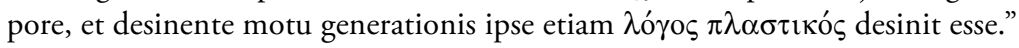


According to Schegk, Aristotle shows that the subject of sperm is an airy spiritus and a foam-like moisture both of which dissolve after the generation of the organic body. When they are dissolved, the plastic logos disappears at the same time. This means that the instrumental cause is replaced by the formal cause, the soul, which remains in the divine vehicle as its "inhabitant." Thanks to this vehicle, which is analogous to the celestial element, the plastic logos cannot only generate the organic body but also the soul, which follows it, can vivify and preserve this body. To Schegk, after the execution of its work, the instrument must leave the achieved product and cannot stay in it as its part any more. The soul replaces the plastic logos in this way. Schegk adds, however, that besides the human soul, nothing is separable from the organic body in living beings, because both the plastic logos and the divine vehicle, and consequently the non-human soul attached to the latter, are not separable from the elemental body. The case of humans is, however, different:

In the generation of man, the plastic logos as its instrumental cause is indeed inseparable whereas the human soul-given that it is not drawn from the potentiality of matter by the plastic logos but is introduced into the matter thanks to the intellect's divine and immortal essence, which may be only created but not generated-will be something created together with this divine body. With this [body], it will be introduced together with the plastic logos into seminal liquid, so that it resides as a certain morphe in the organic body formed by the plastic faculty. The eidos of the human soul was not eternal, as it seems to Plato and Aristotle, but was created by God; this eidos might be, however, separated from the body, and, unlike the other natural forms, might never be generated or corrupted by accident. ${ }^{54}$

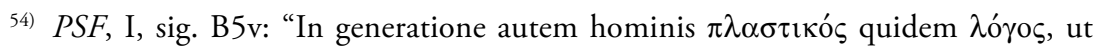

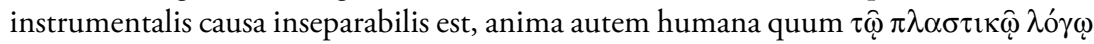
non educatur de potentia materiae, sed introducatur in eam propter divinam et immortalem et non nisi creabilem, non autem generabilem mentis essentiam, cum divino corpore illo concreatum quiddam erit, et cum illo, una cum $\pi \lambda \alpha \sigma \tau \iota \kappa \hat{\varphi} \lambda \lambda^{\prime} \gamma \omega$ in genitali humore includetur, ut plastica facultate formato corpori organico,

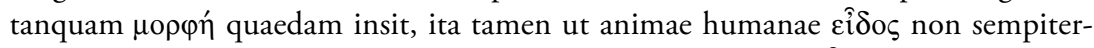
num fuerit, ut Platoni, et Aristoteli videtur, sed a Deo creatum عî̉os, quod a corpore tamen $\chi \omega$ pí $\sigma$ tov sit, et ut aliae formae naturales, nequaquam generabile per accidens aut corruptibile عído $\varsigma$ existat." Aristotle seems to have used the terms eidos and mor- 
According to Schegk, ancient philosophers like Plato and Aristotle think that the human soul exists before it is introduced from outside into the human body to animate this organic body. That is why it is first called "species" (eidos) in the seed and then "form" (morphe) in the organic body. The human soul is separated and separable from the human body in these two phases. Schegk adds that the divine vehicle is "consubstantial" with this soul. Thanks to this spiritual vehicle, the human soul can enter and leave the human body. Then Schegk makes clear the difference between the eidos and the morphe under the authority of Aristotle. The former means a "species which exists by itself," whereas the latter signifies a "species which animates matter." Thus the human soul is an eidos separated from the organic body before the ensoulment but is a separable morphe when it resides in this human body. As for the other animate beings, their soul is only drawn from the potentiality of matter by the plastic faculty and nothing is separable because their eidos does not pre-exist and their morphe is not separable even partially. ${ }^{55}$ Although Schegk's discussion principally concerns here the soul, it should be understood that the plastic logos is always inseparable from the divine vehicle for all living beings including man.

Schegk then invokes the Bible, which he claims also teaches the following points: 1) The human soul enters the organic body thanks to the seed coming from the father; 2) the body is not formed before the soul is created by God; 3) the soul is introduced from outside into this body by the plastic faculty. In Schegk's eyes, even if the ancient philosophers postulated the pre-existence of the noncreated human soul, the doctrine of creation must be defended by Christian philosophers. For this reason, it is to be affirmed that the human soul did not receive its essence from the plastic logos but from the Creator God, who possesses in him all the souls and natures of things. ${ }^{56}$

phe as synonyms, although the latter bears overtones relating to external, visible and concrete aspects. On these terms, see especially André Motte et al., eds., Philosophie de la forme: eidos, idea, morphè dans la philosophie grecque des origines à Aristote (Louvain-la-Neuve, 2003).

55) $P S F, \mathrm{I}$, sig. $\mathrm{B} 5 \mathrm{v}-\mathrm{B} 6 \mathrm{r}$.

56) $P S F$, I, sig. B6r-B6v. 
Before closing his discussion, Schegk enumerates four possible opinions on the origin of human souls: 1) They are eternal and enter bodies at birth and leave them at death (according to Plato and Aristotle); 2) they are created all at once in the beginning of the world, but each of them enters its specific body at a precise moment; 3) they are drawn from the potentiality of matter by the plastic logos as the products of Nature; 4) each of them begins to exist by divine creation at the same moment when body is formed by the plastic logos. Schegk obviously chooses the last option, denying that the human soul is drawn from the potentiality of matter. Invoking the authority of the Bible, he concludes that God forms creatures by the plastic instrument of the seed's nature, whereas only for man God simultaneously creates his soul by Himself and forms his organic body by means of this plastic nature. According to Schegk, God is the Creator of angels whereas the human soul, which shares the angelic essence, is created as the "breath" (spiraculum) of the Creator and is not "produced" by the plastic nature. The everyday creation of the human soul with the formation of its organic body, which is to be animated by this soul, is the ultimate action of the Creator. Although God attributed a primary generative task to the plastic nature, he does not cease to create human souls in order to show that man is not the "product" (plasma) of Nature but the son of God. Schegk concludes:

I believe that, if the philosophers had known the Creator God, they would have agreed with us and would have said that the souls are not contained in the seed and in the seminal liquid of the male before they inform human bodies. In fact, denying the Creator God, or rather being ignorant of Him, they were forced to conclude that, by the spermatic logos, the human soul and its body are generated at the same time and that the human soul is not introduced from outside but is drawn from the potentiality of matter. ${ }^{57}$

57) PSF, I, sig. B7r: "Credo philosophos, si agnovissent Deum creatorem, nobiscum consensuros, et non prius animas, quam informent corpora humana, in semine ac genitali humore masculini sexus contineri dixissent. Nam creatorem Deum negantes,

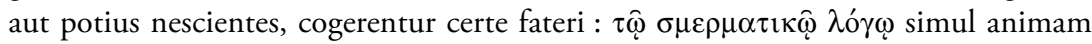
humanam, et corpus ipsi nasci, et non $\theta \dot{\rho} \rho \alpha \theta \varepsilon v$ introduci, sed educi animam humanam de potentia materiae." 
For Schegk, the plastic nature produces all except the human soul, which, endowed with angelic essence, has only the Creator God as its maker. The human soul, or more precisely, the intellect cannot be generated through seminal propagation since it is something "born before" (progenes) Nature. It should be created by what precedes it. That is the Creator God.

\section{Conclusions}

We have in the present article traced the major lines of Schegk's theory of the plastic faculty. For him, this faculty, also called "spermatic logos," is the synonym of the sperm, which is not conceived as visible and material seminal liquid but as a certain dunamis and logos, created by God. It is the instrumental efficient cause of the generation of organic bodies, whereas the principal efficient cause is the parent or heaven. It works, so to speak, as the instrument of the Creator God. It stands in the middle realm between the corporeal and the incorporeal as well as between the material and the immaterial. It is the secondary actuality, that is, the energeia of the essence of the parent's soul. This plastic secondary actuality is substantial because it can generate in matter a substance, that is, the soul. When the soul enters the body formed by the plastic faculty, this faculty is replaced by the soul, which then informs and animates the established organic body, and being replaced by the soul, this faculty disappears. In the Aristotelian tradition, the generative faculty was attributed to the vegetative soul, but this type of soul is almost absent in Schegk's discussion. ${ }^{58}$ Instead, the plastic logos produces the non-human souls and precedes them. Although he always relies upon Aristotle's words, Schegk often interprets them

58) On the vegetative soul, see Aristotle, On the Soul, II.4, 415a14-416b31. Cf. William D. Ross, Aristote (Paris, 1930), 145-146. For Galien, see Moraux, "Galien comme philosophe," 93-94; Phillip De Lacy, "The Third Part of the Soul," in Le opere psicologiche, 43-63. For the early modern period, see Dennis Des Chene, Life's Form: Late Aristotelian Conceptions of the Soul (Ithaca, 2000), 133-138; Guido Giglioni, "Between Sleep and Waking: The Vegetative Soul, the Aristotelian Notion of Life, and Early Modern Philosophy," forthcoming. 
in a unique way and moves away dramatically from the master's thought.

The plastic faculty is always accompanied by a certain divine and ethereal body which is also the vehicle of the soul. This intermediary and spiritual vehicle corresponds by analogy to the celestial element, the aether. Schegk develops a particular interpretation of the Neoplatonic theory of the "vehicle of the soul" (ochema-pneuma) from an Aristotelian perspective. This divine vehicle is also called "ensouled heat," "soul-heat" or "divine element." According to Schegk, the ancient philosophers explained that, by means of this spiritual body, the human soul enters the organic body at birth and leaves it at death. But favouring the Christian point of view, he defends the continuous creation of the human soul by God. For him, the human soul is created by God at the same moment when its organic body is formed by the plastic faculty. ${ }^{59} \mathrm{~A}$ religious tone can thus be found to colour his philosophical discourse. In this extraordinary embryological theory, we may observe a radical challenge formulated by a Protestant physician at the height of Renaissance medical humanism.

It is however only after Schegk's On the Plastic Faculty of Seed, towards the end of the sixteenth century, that the term "plastic force" (vis plastica) really became popular in embryological speculations. Although the publication of his treatise itself came relatively late, Schegk might have formulated his ideas in his lectures at Tübingen before its publication. They could have then be disseminated from the lecture room, particularly in reformed lands, since his lectures attracted many Protestant students, including the famous French Paraclesian Joseph Duchesne alias Quercetanus (1546-1609), who

59) Sennert, another Lutheran, rejected however the idea on the continuous creation of human souls. See Michel Stolberg, "Particles of the Soul: The Medical and Lutheran Context of Daniel Sennert's Atomism," Medicina nei secoli, 15 (2003), 177-203; Hiro Hirai, "Atomes vivants, origine de l'âme et génération spontanée chez Daniel Sennert (et Fortunio Liceti)," Bruniana \& Campanelliana, 13 (2007), forthcoming. Does Schegk see in the plastic faculty as divine instrument the manifestation of the Word of God? At any event, Oswald Croll developed such a view. See my next study, "The Word of God and Universal Medicine in the Paracelsian Chemical Philosophy of Oswald Croll," forthcoming. 
admired Schegk as his "second father." ${ }^{00}$ At any event, the idea of the plastic force was to be discussed intensely in the course of the seventeenth century by such major figures as Kircher, More, Cudworth or Leibniz. But the problem of its diffusion largely exceeds the frame of the present discussion. It is a subject to be fully treated in another study.

60) See Pagel, New Light on Harvey, 56. On Duchesne, see Hiro Hirai, "Paracelsisme, néoplatonisme et médecine hermétique dans la théorie de la matière de Joseph Du Chesne à travers son Ad veritatem hermeticae medicinae (1604)," Archives internationales d'histoire des sciences, 51 (2001), 9-37; Didier Kahn, "L'interprétation alchimique de la Genèse chez Joseph Du Chesne dans le contexte de ses doctrines alchimiques et cosmologiques," in Barbara Mahlmann-Bauer, ed., Scientiae et artes: Die Vermittlung alten und neuen Wissens in Literatur, Kunst und Musik (Wiesbaden, 2004), 641-692. 